\title{
Historical Materialism Seen Through the Lens of Magical Realism: Gender Relationships in Nights at the Circus
}

doi: 10.7358/ling-2015-001-dimi

emilija.dimitrijevic@dellarte.it

I do like to reduce everything to its material basis. It's an odd paradox, I know.

(Angela Carter, Novelists in Interview)

Nights at the Circus (1984) by Angela Carter is a prime example of magical realism. It is a world of a winged woman, respectable prostitutes, ghastly aristocrats, bizarre artists, and many more improbable characters who gain credibility thanks to the consistent and convincing manner of representation. The novel, however, is magical realist in a different sense, too. I would like to adopt this term to refer to the fact that much as Carter's characters and plot may be fantastic, they are rather at home with the ideas of historical materialism. Specific to Carter's writing, as this paper will argue, is the view of gender identity and gender relationships as conditioned by the material conditions of existence and rationalized by men and women as natural. The fact that these dynamics involve fantastic characters and grotesque situations does not change the nature of these dynamics, and this is what gives the novel a depth that has yet to be fully acknowledged.

Before we examine the ways in which gender relationships, magical realism and historical materialism interrelate in the novel, it will be useful to consider briefly the positions these concepts have in writing by Angela Carter and in the criticism of her fiction. "I found myself, as I grew older, increasingly writing about sexuality and its manifestations in human practice," acknowledged Carter, and the whole of her oeuvre bears ample witness to the centrality 
of this theme $(1983,72)$. Accordingly, the focus on gender in criticism Angela Carter's fiction has been prominent, too, and it has been mostly grounded in Judith Butler's theories of performativity (Michael 1996, Ferinhough 1997, Schmidt 1989, Robinson 1991, Rubinson 2001, Trevenna 2002, Toye 2007, Gargano 2007). Butler's work on gender is anti-essentialist in that it sees gender as an expression of culturally determined codes rather than as an expression of a preexisting gender identity. However, what it still has in common with the essentialist positions it criticizes is that it also tends to discuss gender separately from the material background that informs the modes of its "interpellation". For Carter, on the other hand, the concern with gender relationships by no means involved narrowing the focus on gender relationships as such but widening it so as to define these relationships against the backdrop of economic conditions. As she said in an interview with Lorna Sage, one of her central projects was that of representing "women in a certain relation to men, when men are in a certain kind of relation to the economic system they live in" $(1977,56)$. And while it is true that this is a fundamental Marxist stance in that it sees social consciousness and the material basis as mutually interdependent, it is worth remembering that Marxist theory itself does not treat gender relationships in such terms. Traditional Marxist thought defines social consciousness, or ideology, as the "production of ideas, of conceptions, of consciousness" that shape "politics, laws, morality, religion, metaphysics, etc." and represent "the ideal expression of the dominant material relationships, the dominant material relationships grasped as ideas" (Marx and Engels 2001, 101). It further classifies ideology as a "false consciousness" because it presents itself as self-evident and universal while obfuscating the fact that it is determined by the material conditions of life, which in turn it expresses and legitimizes. But classical Marxism does not look at gender relationships in the same terms. It examines man/woman relationship in context of the family seen as a domestic economic unit emerging with the change in the communal division of labour and the distribution of products, but it does not go on to consider how these conditions determine the notions of gender so that, as we will see, gender relationships themselves become "the ideal expression of the dominant material relationships".

If Carter's concern with gender and Marxist theory has led her to radically re-examine both, it would be expected of such writing to figure prominently in more recent Marxist criticism and feminist Marxism. This, however, is not the case for a series of reasons. In the first place, current Marxist criticism tends to view postmodern fiction as not seriously engaged with historical reality. It has frequently perceived postmodern writing, as Gerald Graff put it, as indulging in "the trivializing freedom of infinite fabulation" in a world undergoing an unprecedented process of commodification and social regimentation (1975, 307). In influential works by Frederic Jameson and Terry Eagleton, postmod- 
ernism has been defined as a cultural style of advanced capitalism, in which a distrust in categories traditionally associated with humanism has led to a waning of historicity, content, identity, on one hand, and to playfulness, dephtlessness and parody, on the other one. For Jameson,

reference and reality disappear altogether, and even meaning - the signified - is problematized. We are left with that pure and random play of signifiers that we call postmodernism, which no longer produces monumental works of the modernist type bur ceaselessly reshuffles the fragments of preexistent texts, the building blocks of older cultural and social production, in some new and heightened bricolage. $(1990,96)$

An even more dismal stance towards postmodernism can be found in Terry Eagleton's writing. As Eagleton, among others, observes, the changes in the production of culture are inseparable from the changes in the modes of material production. The first major transformation of this kind takes place in modernity, when the creation of culture is rendered independent from the political institutions that have traditionally given it support, but when culture itself becomes commodified. The modernist opposition to mass production and consumption of culture seems thus to have only briefly delayed the second major shift in the production of culture - the one that corresponds to the postmodern turn. It is at this point that, as Eagleton observes, the production of culture becomes once again integrated in the forces that have hegemony in society, with the difference that its character is now not primarily political but economic. Thus in late capitalism we find "a revival of the premodern integration of the symbolic and social, but now, more precisely and dispiritingly, in the form of a recoupling of the symbolic and economic. Cultural production rejoins general production after the fissurings and estrangements of modernity, but now thoroughly under the sway of the commodity form" $(1997,3)^{1}$.

While these observations are generally valid, it is also true that in general, "Despite the loud and vigorous denunciation of postmodernism by some Marxist, there has been very little actual analysis of specific postmodern art works by them" (Hutcheon 1988, 211). At the same time, as a work that "articulates feminist concerns about female identity, history and the body in a way that clearly demonstrates a knowledge of philosophers and theorists on these subjects [...] frequently extend[ing] and complicat[ing] our understanding of the issues involved," Nights at the Circus calls for exactly that kind of anal-

1 See also The Illusions of Postmodernism, where Eagleton argues that the "rich body of work on racism and ethnicity, on the paranoia of identity-thinking, on the perils of totality and the fear of otherness, would no doubt be of considerable value. But its cultural relativism and moral conventionalism, its skepticism, pragmatism and localism, its distaste for ideas of solidarity and disciplined organization" render "postmodernism in the end part of the problem rather than of the solution" (1996, 134-35). 
ysis and triggers controversy (Stoddart 2007, 21). Critics like Robert Clark, for instance, have criticized Carter on account of her supposed "primary allegiance $[\ldots]$ to a postmodern aesthetics that emphasizes the non-referential emptiness of definitions," arguing that "Such a commitment precludes an affirmative feminism founded in referential commitment to women's historical and organic being" $(1987,158)$. On the other hand, it has also been pointed out that Carter's writing is clearly politically committed in that it explores "the material world in which women are daily oppressed as women [...] within specific political, cultural, historical, economical, and ideological contexts" and because it traces "the processes by which 'official' women - that is, individual sexed female - are socially and discursively constructed as Woman according to the needs of the dominant, 'official' sex, men" (Michael 1996, 493, Robinson 1991, 77). Important as these observations are because they identify the social character of cultural concepts, they do not examine them beyond the context of "women's subjectivity [...] de-formed by the social power of patriarchal stereotypes of femininity" (Schmidt 1989, 73). For Carter, on the other hand, understanding how "that fiction of my 'femininity' was created, by means outside my control, and palmed off on me as the real thing" necessitated a deeper engagement with not only cultural discourse but also with socio-economic conditions out which it emerges, as we will see in the case of Nights at the Circus, to which we will now turn $(1983,70)$.

"Is she fact or is it fiction?" is the novel's central question and the question that Fevvers, the winged celebrity of the turn of the nineteenth century, turns into an impossible riddle and flaunts as her publicity stunt ${ }^{2}$. This, however, is not the case of other female characters, whose lived experience is by and large explained by fictions, and especially fictions of femininity, while it is really determined by the logic of commodification. The first such example in the novel is the brothel in which Fevvers grows up. Rather than a house of sin, the brothel is a market place, where women captained by Ma Nelson trade their only and the most profitable possession - their bodies. Here the real conditions of prostitution expose the falsity of romanticised rationalizations:

But what followed was [...] only poor girls earning a living, for though some of the customers would swear that whores do it for pleasure, that is only to ease their consciences, so that they will feel less foolish when they fork out hard cash for pleasure that has no real existence unless given freely - oh, indeed! we knew we only sold the simulacra. No woman would turn her belly to the trade unless pricked by economic necessity. (39)

2 This essay will not examine the relationships between the protagonists of the novel but gender relationships in general. For a more detailed account of the interactions between Walser and Fevvers, see Intimacy and Identity in the Postmodern Novel (2008) by Emilija Dimitrijevic. 
Soon enough, however, it becomes more difficult to see prostitution simply for what it is: the commodification of gender relationships. As we leave the brothel and move to Madame Schreck's museum of women monsters, the clients of that house cease to romanticise and start to demonise prostitution. At the same time, the tone becomes more desolate and the economic aspect more indefinite. Not because of Fevvers, though, who comes to Madam Schreck for money and doesn't forget it for a moment. It is those other denizens of the museum such as the Wiltshire Wonder, for instance, who tend to overlook this fact and see their experience as a natural consequence of their unnatural condition. Their life stories and commentaries are part of the London interview with Walser, and so still conveyed by Fevvers, but the point of view is their own, so remarks on the economic reality of social relations become rarer and the stress falls on "a tragic case," a "rehears[al] of an eternity of fearful memories," and "hearts that beat, like yours, and souls that suffer" (63-68).

These views of reality are distorted and typically ideological in that "the cognitive structure of an ideological discourse is subordinated to its emotive structure" (Eagleton 2001, 64). They are examples of "false consciousness" in the sense that, as Engels put it, they represent "occupation with thoughts as with independent entities, developing independently and as subject only to their own laws" while disregarding actual life conditions $(2001,57)$. But it would be wrong to assume that ideology is confined only to thoughts and ideas. Much as ideology may be "false" because detached from reality and distorting the nature of social relationships, it at the same time very "real" because, in the first place, it naturalizes this distortion and, secondly, makes it constitutive of real social practices. This is true for both Ma Nelson's and Madame Schreck's women, whose existence is in both cases regulated through a market system but explained in terms of a pre-given identity. Only, in the latter case it becomes harder to discern the economic factor: the histories of Madame Schreck's women can too easily be interpreted as determined by the women's "monstrous" nature, when we should really be astonished to see a replica of Ma Nelson's brothel in different colours and scales.

The obfuscation of economic relationships continues throughout the novel as Carter introduces other characters who further rationalise and profit from murky relationships between economy and ideology. With Colonel Kearney, whose circus Fevvers has joined, and the German spiritualist Herr M., the novel draws the curtains on the house of sin of Part One and opens them on the house of mirth and the house of grief of Part Two. Even though the economic character of these settings remains as significant as before, it also becomes more veiled. The Colonel's circus, for instance, is an enterprise built upon basic human fondness for entertainment and shared by the Colonel, the audience and the circus stars alike. The fact that the performers are skillful and 
join the circus of their own free will seems to suggest that the novel is moving from the realm of predetermined relations towards a culture of laissez-faire and free contracts. Even the Colonel's bonhomie sets him apart from the ruthless exploiters of Madam Schreck's type. The circus model is thus apparently juster, more egalitarian, patriotic and human-faced compared to the previous one. But only apparently, since it is nonetheless part of Colonel Kearney's profit making schemes. And much the same applies to Herr M., who is in the business of assuaging grief but, in other respects, is very similar to the Colonel. $\mathrm{He}$ is aware of the importance of skilfulness in creating an illusion and possesses a shrewd sense for making money out of non-productive work - "why steal when there is more intellectual satisfaction to be obtained from cheating?" (134) - as well as a talent for sugar-coating it:

So you can see there were still traces of common humanity in Herr M., and these he often applauded in himself: did he not comfort, did he not console? Did he not, out of the goodness of his compassionate heart, assuage the suffering souls who brought their pain into his parlour? Had he not hit upon that one compassionate innovation that set him apart from other mediums, could he not sell his unhappy clients authentic pictures of the loved and lost ones, that proved, in whatever world they now inhabited, they flourished still? (136)

Here again, the narrative space given to actual economic relationships in Herr M.'s parlour is intentionally minimal. In the circus, their only sign are the Dollar buckle sign on the Colonel's belt and the motto of the games "A fool and his money are soon parted," and in Herr M.'s account of his activities, attention is paid to circumstances, conjunctures, and technical devices used to enhance the illusion, while the very idea of economic interests becomes as ghostly and intangible as the spirits he summons. In both cases, Carter shows that what these characters are doing and what they think they are doing has become much more entwined than in the previous section, while basic human needs for amusement and avoidance of suffering undergo the process of commodification.

What is more, there is another dark side of this story, which unfolds with the character of Mignon, the character based upon Goethe's Mignon and revisited by Carter. Mignon's past does not belong to plot proper. It is part of the exposition and thus unknown to other characters, and what is worse, it is unknown to Mignon herself, who finds in her short memory a tentative protection from perpetual sexual and physical violence. This is important as it signals a drastic discrepancy between the apparently more egalitarian world of the circus and the experience of utter abuse and desolation, which remains entirely unacknowledged and voiceless. And it is illuminating to look at real contemporary data on prostitution to realize that Mignon is far more than a 
tragic fictional character. The global report on sexual exploitation released by The Fondation Scelles in 2012 states that there are currently in between forty and forty two million people involved in the sex industry today. Seventy five percent of these are between thirteen and twenty five years of age, and almost half of the victims of human trafficking networks are children and youths under eighteen years old. Prostitutes, both men and women, are exposed to severe physical and psychological violence, which comprises unprotected sex acts, beatings, and rapes and can result in post-traumatic mental and somatic disorders. That Mignon's past, which is based on just such a reality, should not be part of the characters' conscious experience is significant because it represents a sharp critique of modern democracies, where the phenomenon of prostitution tends to be submerged rather than truly confronted.

In Part Three, as the circus leaves St Petersburg and moves to Siberia, the emphasis on the economic nature of social conditions further diminishes, while the ideological dimension strengthens and ramifies taking first the form of the state and then of religion. The state, to begin with, represents what Engels defined as a higher form of ideology - a form of political order based upon the existing social order, but deviating all social attention to the state apparatus as such:

The state presents itself to us as the first ideological power over man. Society creates for itself an organ for the safeguarding of its common interests against internal and external attacks. This organ is the state power. Hardly come into being, this organ makes itself independent vis-à-vis society [...] But once the state has become an independent power vis-à-vis society, it immediately produces a further ideology. It is among professional politicians, theorists of public law and jurists of private law that the connection with economic facts gets well and truly lost. (55-56)

As regards gender relationships, inequality is at this point sanctioned by tradition, justified by legal systems, corroborated by science, and held in place by the forces of order. We find all these elements interlocking in a brief paragraph that deals with Olga Alexandrovna's conviction for the murder of her violent husband:

"You are in luck," the turnkey told the convicted woman after the French phrenologist measured her head and asked the court that she should be transferred to the Countess's 'scientific establishment for the study of female criminals'. Good luck indeed! No hard labour, no flogging for Olga Alexandrovna, bound as she was for the Countess's seminary. And the turnkey laughed, raped her and chained her. Next day, she set out for Siberia. (211)

It comes as no surprise in this totalitarian context that the Countess P.'s panopticon does not aim to "punish" the women - as if they had not been system- 
atically abused all along - but to "rehabilitate" them so that they themselves may re-embrace social mores. As Foucault argued in Discipline and Punish, the model of the panopticon signals a shift from a society that publicly displays power and inflicts punishment towards a society that operates through surveillance and self-discipline. Designed by Bentham, who advocated the principle of the greatest happiness of the greatest number, but did not believe in the equal rights of men nor included freedom among their rights, the panopticon thus becomes symptomatic of a self-regulating social system in which an effective criminal law controls the interests of the individual and makes them coincide with those of society. Of course, the fact that we encounter women and men outlaws in Siberia testifies that, however huge, the power of the state is not boundless. But that of itself is no guarantee of change. For female rebels, opting out of society is a necessary but not necessarily a sensible action, and for male bandits, the rebellion against authority does not signify a search for a new and alternative reality but just the opposite - falling back on even more obsolete social model of the extended family.

The last and supreme example of ideology Carter presents us with is that found in the Siberian village, where it takes the form of religion. Religion, along with philosophy, represents the highest form of ideological discourse because, to borrow again from Engels, it "stands furthest away from material life and seems to be most alien to it" $(2001,57)$. By contrast to the state, religion does not articulate itself in the social institutions as thoroughly and the modes and relations of productions it accompanies are far more rudimentary. But this does not alter the fact that, no matter how primitive the level of material production, it still constitutes the material basis of the ideological discourse. The point tends to be disguised by the fact that "ideology [...] once it has arisen, develops in connection with the given concept-material, and develops this material further; otherwise, it would not be an ideology, that is, occupation with thoughts as with independent entities, developing independently and subject only to their own laws" (Engels 2001, 57). Accordingly, in the case of religion, the material nature of social relationships does not stand out as much as in developed economic systems, while the ideological discourse inflates the epistemological space to such an extent as to achieve the status of an independent reality.

In the novel, this is exemplified by a sharp separation between the sense of the real and perceived reality. In Part Three, the narrator observes that the Siberian villagers "knew the space they saw. They believed in a space they apprehended. Between knowledge and belief, there was no room for surmise or doubt. They were, at the same time, pragmatic as hell and, intellectually speaking, permanently three sheets in the wind" (253). Because they do not perceive their perceptions of reality as theirs but as real, their interpretation of 
the world does not necessitate an emotional investment like that of the Wiltshire Wonder, Colonel Kearney or Herr M. to corroborate it. In other words, the emotional structure does not need to supplant the cognitive one because it presents itself as an independent cognitive structure in itself.

For gender relationships, this implies that women's subjection is governed by myths and taboos. In this section of the novel, the narrative doesn't deal with new examples of gender relationships as such, but it tells the story of a pregnant woman obliged by custom to leave the village, give birth unassisted, and stay ten days in seclusion with her baby to protect it from malignant spirits. Although there are no man/woman relationships per se to consider here and the story's momentum drives the reader to find out more about the custom and about what happens next to the woman and the baby, it is obvious that giving birth has something to do gender relationships, just as it is obvious that a woman left to her own devices in childbirth is symptomatic of the woman's condition in a social structure that leaves her "in bondage to her reproductive system [...] tied hand and foot to Nature" (283).

The novel thus concludes at a point diametrically opposite to where it started. The strong initial emphasis on the material basis of social relationships gives way to more emotionally coloured accounts and is followed by a vision of reality entirely independent from reality itself. This is accompanied by a progressive reduction of Fevvers's involvement as a narrative voice: by contrast to the first two sections of the novel, Fevvers does not provide a direct commentary or an indirect counter-argument. In these two sections, her presence in general and her own relentless focus on money help to set a perspective even when she is not actually present with the other characters. But in the last section of the novel, Fevvers and the circus crew do not even meet the women escapees and for the most part remain outside the Shaman's village. The only group of outlaws they encounter are the bandits who dynamited the train. Here Fevvers's own perspective itself gets out of focus: she is still capable of irony towards the outlaws and their idea of social justice, but she seems to be more interested in her own romantic quest at this point, as confirmed by the fact that it is Lizzie who lectures the escapee on the philosophy of historical materialism and warns Fevvers herself about the risks of running after Walser. As a result, the very idea of the economic and political nature of social relations becomes more indistinct, amounting to few sporadic remarks such as that the shaman didn't take part in "spirits forbid! - productive labour" and "at the moment [...] lived comfortably on the surplus, paid in kind by grateful patients or those whose dreams he had interpreted with a happy degree of accuracy" (264).

This course of events - the displacement of the narrative from urban London to St Petersburg and Siberia, Fevvers's diminishing control of the 
narrative, the representation of ever-stronger forms of ideology, and Walser's amnesia - all would seem to suggest a progressive loss of touch with reality. But it would be more precise to say that, notwithstanding such a drift and all its Fellinian protagonists, the novel accurately represents gender relationships through the blueprint of historical materialism. Classical Marxist theory begins with the analysis of capitalism under the Industrial Revolution and identifies the main relations among production, labour, property and its distribution, which it then investigates in less developed economic contexts of manufacturing, guild handcrafting, and communal economy. On this basis, it demonstrates that economic relations are the root of all ideological thinking, but that this fact is less obvious in the context of less developed economies or in the highest forms of ideology such as philosophy and religion, which are purportedly not concerned with the material life. Nights at the Circus proceeds similarly: it starts with gender relationships most obviously fashioned as economic transactions but explained away as natural, moves on to those apparently governed by more democratic and less economic interests, and finally, it looks at gender relationships where they appear the least connected with the material and dominated by the supernatural, showing that in all these cases economic relationships are not less decisive but rather differently naturalized.

Because of its materialist outlook, Nights at the Circus stands unique in the genre of magical realism while also providing a complex and provocative account of gender relationships. It suggests a feminist agenda which, while acknowledging the role of social discourses in the constitution of gender, concerns itself not only with social codes but also with the material grounds that inform them. In fact, because it has such a strong foothold in socioeconomic reality the novel has the confidence to "juggle" with humour and irony, advertise Fevvers but bring in Lizzie, too, and invite the reader to spend few nights at the circus and yet teach a lesson in historical materialism. And it is for this reason that, in the end, I have to agree with Clark that "Truly dialectical understanding of our cultural predicament can only come out of a cross-questioning of the imaginative and the analytic" $(1987,152)$. Only, it is precisely to Nights at the Circus that we should turn for an example of such writing.

\section{REFERENCES}

Carter, Angela. 1983. "Notes from the Front Line.” In On Writing and Gender, edited by Michelene Wander, 69-77. London: Pandora. (1984) 1994. Nights at the Circus. London: Vintage Classics. 
Charpenel, Yves. 2014. Rapport mondial sur l'exploitation sexuelle: la prostitution au coeur du crime organisé. Fondation Scelles. Paris: Economica.

Clark, Robert. 1987. “Angela Carter's Desire Machine.” Women's Studies 14: 147-61.

Dimitrijevic, Emilija. 2008. Intimacy and Identity in the Postmodern Novel. Oxford, Bern, Berlin, Bruxelles, Frankfurt am Main, New York, Wien: Peter Lang.

Eagleton, Terry. 1979. "Ideology, Fiction, Narrative.” Social Text: 62-80. 1996. The Illusions of Postmodernism. London: Blackwell. . 1997. "The Contradictions of Postmodernism." New Literary History 28: 1-6.

Engels, Frederick. 2001. Ludwig Feuerbach and the End of Classical German Philosophy. London: GBR Electric Book Company.

Ferinhough, Anne. 1997. “'Is She Fact or Is She Fiction?’: Angela Carter and the Enigma of Woman.” Textual Practice 11: 89-107.

Gargano, Elizabeth. 2007. "The Masquerader in the Garden: Gender and the Body in Angela Carter's The Magic Toyshop." Women's Studies 36: 57-78.

Graff, Gerald. 1975. "Babbitt at the Abyss: The Social Context of Postmodern American Fiction." TriQuarterly 33: 305-37.

Haffenden, John. 1985. Novelists in Interview. London: Methuen.

Hutcheon, Linda. 1988. A Poetics of Postmodernism: History, Theory, Fiction. London and New York: Routledge.

Jameson, Frederick. 1990. Postmodernism, or, The Cultural Logic of Late Capitalism. Durham: Duke University Press.

Marx, Karl and Frederick Engels. 2001 [1970]. The German Ideology Part One, with Selections from Parts Two and Three, together with Marx's "Introduction to a Critique of Political Economy," edited by J.C. Arthur. New York: International Publishers.

Michael, Magali Cornier. 1996. Feminism and the Postmodern Impulse. Post-World War II Fiction. New York: State University New York Press.

Robinson, Sally. 1991. Engendering the Subject: Gender and Self-Representation in Contemporary Women's Fiction. SUNY Series in Feminist Criticism and Theory. Albany: State University of New York Press.

Rubinson, Gregory J. 2000. “'On the Beach of Elsewhere': Angela Carter's Moral Pornography and the Critique of Gender Archetypes.” Women's Studies 29: 717-40.

Sage, Lorna. 1977. “The Savage Sideshow: A Profile of Angela Carter.” New Review: 51-57.

Schmidt, Ricarda. 1989. "The journey of the subject in Angela Carter's fiction.” Textual Practice 3: 56-75.

Stoddart, Helen. 2007. Angela Carter's "Nights at the Circus”. New York: Routledge.

Toye, Margaret. 2007. “'Eating Their Way Out of Patriarchy: Consuming the Female 
Panopticon in Angela Carter's Nights at the Circus." Women's Studies 36: 477-506.

Trevenna, Joanne. 2002. "Gender as Performance: Questioning the 'Butlerification' of Angela Carter's fiction.” Journal of Gender Studies 11: 267-76.

\begin{abstract}
Nights at the Circus (1984) by Angela Carter is widely recognized as a masterpiece of magical realism. At the same time, the novel stands out in the literary genre because of its distinctly materialistic outlook. This essay argues that specific to Carter's writing is the view of gender discourse as yet another form of idealization of dominant economic relationships. Classical Marxist theory begins with the analysis of capitalism under the Industrial Revolution and extends it to consider its implications in less developed economies. The novel proceeds similarly: it starts with gender relationships most obviously fashioned as economic transactions but explained away as natural, moves on to those apparently less governed by economic interests, and finally examines gender relationships where they appear to be dominated by the supernatural, showing that in all these cases economic relationships are not less decisive but rather differently naturalized.
\end{abstract}

